\title{
Adverse effects induced by diclofenac, ibuprofen, and paracetamol toxicity on immunological and biochemical parameters in Swiss albino mice
}

\author{
Soha Gomaa
}

\begin{abstract}
Background: Nonsteroidal anti-inflammatory drugs (NSAIDs) are generally used to reduce pain in different diseases acting as anti-inflammatory, antipyretic, and analgesic. Paracetamol is a nonprescription drug extremely used for antipyresis and analgesia. In spite of their beneficial effects, NSAIDs have been notified to be linked with some adverse effects. The present study was conducted to elucidate the comparative biochemical and immunological changes in mice treated with diclofenac (Diclo), ibuprofen (Ibu), or paracetamol (Para).

Methods: Swiss albino mice were divided uniformly into seven different groups. Mice were intraperitoneally (i.p.) administered with Diclo (7.4 and $14.8 \mathrm{mg} / \mathrm{kg}$ ), Ibu (60 and $120 \mathrm{mg} / \mathrm{kg}$ ), and Para (36.7 and $73.4 \mathrm{mg} / \mathrm{kg}$ ) daily for 1 month against saline-treated mice served as control. Blood samples were collected, and the assessments of some biochemical and immunological markers were measured.

Results: No significant change was observed in total WBC count; however, relative values of leukocytes indicated relative neutropenia, lymphopenia, monocytosis, and basophilia in all treatments. Furthermore, all tested drugs caused elevation in the number of bone marrow (BM) cells; however, splenocyte count was significantly decreased post Para and Ibu administration, but Diclo treatment showed increase in splenocyte count. Additionally, the number of thymocytes and lymph node cells had no significant changes. Alternations of levels of serum ALT and AST were markedly changed in a dose-dependent manner, but no significant differences were monitored in the levels of serum urea and creatinine.

Conclusions: It could be concluded that administration of diclofenac, ibuprofen, or paracetamol may induce immunological and biochemical perturbations and further investigations are required to assess their toxicity in the biological system.
\end{abstract}

Keywords: NSAIDs, Paracetamol, Immunological-biochemical studies, Toxicity

\section{Background}

There are three general categories of analgesic agents that frequently used for the most widespread types of pain: acetaminophen, nonsteroidal anti-inflammatory drugs (NSAIDs), and opioids (Labianca et al., 2012; McCarberg \& Gibofsky, 2012; Barr, Fraser, Puntillo, et al., 2013; Blondell, Azadfard, \& Wisniewski, 2013). NSAIDs are effective analgesic agents in relieving pain

Correspondence: sohassd@science.tanta.edu.eg

Immunology and Biotechnology Division, Zoology Department, Faculty of Science, Tanta University, Tanta 31527, Egypt and inflammation by a variety of diverse mechanisms (Ong, Lirk, Tan, \& Seymour, 2007; Roelofs, Deyo, Koes, Scholten, \& Van Tulder, 2008; Ripamonti, Bandieri, \& Roila, 2011). There are two main types of NSAIDs, traditional nonselective NSAIDs (tNSAIDs) that nonspecifically inhibit both COX-1 and COX-2, and selective COX-2 inhibitors (Nalamachu, 2013; Fonseca, 2017). One major target of NSAID action is their ability to inhibit the activities of cyclooxygenase enzymes (COX-1 and COX-2) that are responsible for the conversion of arachidonic acids into prostaglandins employing a 
variety of different mechanisms (Zerbini et al., 2011). NSAIDs are connected to a number of potential tolerability issues, most notably gastrointestinal, renal, and hepatic effects in addition to their influence on clotting function (Siroka \& Svobodova, 2013) and direct relation to their biliary excretion (Mohammed, 2015). NSAIDs such as aspirin, ibuprofen, naproxen, and diclofenac are extensively used as analgesics and anti-inflammatory agents producing their therapeutic effects through the inhibition of prostaglandin synthesis (Klaassen, 2001).

One of the ordinary used analgesics, diclofenac (Diclo) which is one of the most frequently prescribed nonselective NSAIDs worldwide, has strong analgesic, antipyretic, and anti-inflammatory effects and generally used in human and veterinary practice (Ramesh, Jayakumar, Narayana, \& Vijayasarathi, 2002) as premier treatment for inflammatory, degenerative rheumatic diseases and pain conditions (Morgan, 1999; Oaks et al., 2004). It has severe pathologic effects such as peptic ulceration, gastrointestinal bleeding, hepatotoxicity, renal papillary necrosis, and renal failure on long-term treatment of the drug (Aydin et al., 2003). As well it reduces intracellular concentrations of free amino acid in leucocytes, perhaps by altering release or uptake (Juni, Rutjes, \& Dieppe, 2002). Therefore, a considerable concern should be taken to study the toxicity of diclofenac due to its clinical use and adverse effects.

Ibuprofen (Ibu) is an over-the-counter (OTC) drug and widely used as an analgesic, antipyretic, and antiinflammatory drug globally (Bushra \& Aslam, 2010), both acutely and chronically (Rainsford, 2009). The mechanism of action of Ibu, like other NSAIDs, is the inhibition of both COX-1 and COX-2 and its analgesic, antipyretic, and anti-inflammatory activities are accomplished basically through COX-2 inhibition; however, inhibition of COX-1 is responsible for its undesired effects on gastrointestinal mucosa and accumulations of platelets (Shafi et al., 2012). They are commonly associated with gastrointestinal (GI) toxicity (Higuchi et al., 2009) and alterations of renal function (Aprioku \& Uche, 2013). The frequent and widespread use of Ibu and other NSAIDs is likely to increase the prevalence of their adverse effects.

Paracetamol (Para) is vastly utilized as an over-thecounter analgesic and antipyretic drug. At therapeutic doses, it is conceived a safe drug; however, it can give rise to adverse effects such as nephrotoxicity, extrahepatic lesions, hepatic necrosis, and even death in experimental animals and humans when taken in overdose (Bessems \& Vermeulen, 2001; Hinson, Roberts, \& James, 2010; McGill, Williams, Xie, Ramachandran, \& Jaeschke, 2012). Its overdose is also associated with an elevation in the levels of inflammatory cytokines and nitrogen oxide (NO) in serum, macrophages, and hepatocytes (Jaeschke, Williams, McGill, Xie, \& Ramachandran, 2013).
Because of widespread and frequent usage of NSAIDs, regular toxicological evaluation becomes essential. Also, literature review has revealed a lack of sufficient reports about repeated dose pathogenicity study of Diclo, Ibu, and Para regarding immunological and biochemical changes in mice. Therefore, the current research has mainly been intended to inspect the immunological and biochemical perturbations in mice which were administered with repeated doses of Diclo, Ibu, and Para for 1 month.

\section{Methods \\ Mice}

Male Swiss albino CD-1 mice were obtained from the Egyptian Company for Production of Vaccines and Sera (VACSERA), Cairo, Egypt. Animals were 6 weeks old and weighed between 20 and $28 \mathrm{~g}$ at the onset of the experiment. They were handled and kept in a specific pathogenfree facility at the Faculty of Science, Tanta University, in agreement with the ethical guidelines of Egyptian National Research Center, Cairo, Egypt. All animals were settled under the same environmental conditions for 1 week before experimentation for acclimatization and to ensure normal growth and behavior. The mice were held under typical laboratory conditions (temperature $22{ }^{\circ} \mathrm{C} \pm 2{ }^{\circ} \mathrm{C}$; $12 \mathrm{~h}$ light-12 $\mathrm{h}$ dark cycle and kept in plastic cages with free access to the commercial basal food and water.

\section{Drugs}

The tested drugs, diclofenac sodium (Diclo) (each tablet contains $50 \mathrm{mg}$ diclofenac sodium, Novartis Pharma, Cairo, Egypt), ibuprofen (Ibu) (each tablet contains 200 mg ibuprofen, Kahira Pharmaceuticals \& Chemical Industries Company, Cairo, Egypt), and paracetamol (Para) (each tablet contains $500 \mathrm{mg}$ active drug, Arab Drug Company, Cairo, Egypt), were purchased from a public drug store (Tanta, Egypt). Each tablet was crushed to fine powder and dissolved in saline at appropriate concentrations.

\section{Experimental design}

Mice were divided into seven groups of 10 animals each. Group1 was administrated with saline (i.p.) as a control group; group2 and group3 i.p. inoculated with Diclo $(14.8 \mathrm{mg} / \mathrm{kg}$, five times less than LD50 and $7.4 \mathrm{mg} / \mathrm{kg}$, 10 times less than LD50 respectively (EC-SDS diclofenac, 2014)); group4 and group5 i.p. injected with Ibu $(120 \mathrm{mg} / \mathrm{kg}$, five times less than LD50 and $60 \mathrm{mg} / \mathrm{kg}, 10$ times less than LD50 correspondingly (Adams, Bough, Cliffe, Lessel, \& Mills, 1969)); and group6 and group7 i.p. injected with Para $(73.4 \mathrm{mg} / \mathrm{kg}$, five times less than LD50 and $36.7 \mathrm{mg} / \mathrm{kg}, 10$ times less than LD50 separately (EC-SDS Acetaminophen, 2015)) daily for a period of 1 month. At the end of treatment, three mice from 
each group were euthanized by cervical dislocation at fasting state. Prior to the scarifying, blood samples were collected from the retro-orbital plexus for immunological and biochemical analyses.

\section{Hematological analysis}

Blood parameters were proceeded for hematological analysis using a Nihon Kohden automated hematology analyzer (model MEK-6318K, Japan), including leucocytes (WBC) $\left(10^{3} / \mu \mathrm{l}\right)$ and their differential relative\% (neutrophils, lymphocyte, basophils, and monocytes) in peripheral blood (PB).

\section{Preparation of sera samples}

At the end of experiment, mice were sedated with light ether and blood was drained from their retro-orbital plexus before being euthanized by cervical displacement at fasting state. Blood samples were gathered in plastic test tubes and allowed to stand for $3 \mathrm{~h}$ to confirm complete clotting. The clotted blood samples were centrifuged at $3000 \mathrm{rpm}$ for $10 \mathrm{~min}$ and the clear sera samples were aspirated off and stored frozen at $-80{ }^{\circ} \mathrm{C}$ for biochemical analyses.

\section{Analysis of liver and kidney functions}

The activity of the subsequent markers was determined colorimetrically using the standard ready-to-use kits and methods of Human (Human Gesellschaft Für Biochemica and Diagnostica MBH, Germany) using a fully automated biochemistry analyzer (Vita lab Selectra E, Germany): serum aspartate aminotransferase (AST) (U/ l), alanine aminotransferase (ALT) (U/l), creatinine (mg/ $\mathrm{dl})$, and urea $(\mathrm{mg} / \mathrm{dl})$. The manufacturer's instructions for each biochemical parameter were firmly pursued in the course of the investigations.

\section{Thymocyte, splenocyte, lymph node, and bone marrow cell counting}

Spleen, thymus, lymph nodes, and tibia and femur bones were aseptically removed and placed individually in a $60 \mathrm{~mm} \times 15 \mathrm{~mm}$ petri dish with PBS. Single-cell suspension and count of cells were prepared as described previously by Lutz et al. (1999) and Diaz-Montero et al. (2009). Briefly, splenocytes, thymocytes, and lymph node cells were isolated by dissociating spleen, thymus, and lymph node respectively on $60-\mu \mathrm{m}$ mesh sieve screens (Sigma, St. Louis, MO) and lysing of RBC was carried out with ACK (Ammonium-Chloride-Potassium) buffer. Isolated cells were washed and diluted in supplemented PBS. Tibia and femur were extracted aseptically and the bone marrow $(\mathrm{BM})$ cells were flushed from tibia and femur of mice. BM cell suspension was subjected to ACK buffer for the depletion of RBC then washed and diluted in PBS. Cell viability and count analysis had been done by the trypan blue exclusion method using a hemocytometer.

\section{Statistical analysis}

The data were expressed as mean \pm standard error of the mean $(n=3)$. Statistical differences among the prospective groups and their counterparts were analyzed using one-way analysis of variance (ANOVA) as part of an SPSS software package (v.16.0 for Windows, 2007; SPSS, Inc., Chicago, IL) by a post hoc test followed by Dunnett's for several comparison tests to compare treated groups against respective controls. Significant differences were indicated by $p$ values $<0.05$.

\section{Results}

The current study was conducted to evaluate whether daily administration of different analgesics: Diclo, Ibu, and Para induced immunological and/or biochemical changes in mice. The present findings indicated that 1-month continuous treatment with Diclo, Ibu, and Para has altered the immuno-biochemical parameters in the processed mice.

The present study revealed a minor increase in the total WBC count in Diclo- (7.4 and $14.8 \mathrm{mg} / \mathrm{kg}$ ), Ibu(60 and $120 \mathrm{mg} / \mathrm{kg}$ ), and Para (36.7 and $73.4 \mathrm{mg} / \mathrm{kg}$ )treated mice comparing to saline-treated mice (Table 1). Also, there was slight decrease in the relative percentage of lymphocytes in all examined drugs. The treatment with Diclo (7.4 mg/kg), Ibu (60 $\mathrm{mg} / \mathrm{kg})$, and Para $(36.7 \mathrm{mg} / \mathrm{kg}$ ) caused obvious increase in relative\% of monocytes and increasing dose of Diclo $(14.8 \mathrm{mg} / \mathrm{kg})$ and $\mathrm{Ibu}(120 \mathrm{mg} / \mathrm{kg})$ decreased their relative\%; however, increasing dose of Para $(73.4 \mathrm{mg} / \mathrm{kg})$ significantly increased the relative\% of monocytes compared to control mice.

Data presented in Table 1 further showed that administration of Diclo $(7.4 \mathrm{mg} / \mathrm{kg}), \mathrm{Ibu}(60 \mathrm{mg} / \mathrm{kg})$, and Para $(36.7 \mathrm{mg} / \mathrm{kg}$ ) showed a decrease in neutrophil relative\%, whereas increasing dose of Ibu $(120 \mathrm{mg} / \mathrm{kg})$ and Para $(73.4 \mathrm{mg} / \mathrm{kg}$ ) more reduced relative\% of neutrophils, but increasing dose of Diclo $(14.8 \mathrm{mg} / \mathrm{kg})$ increased relative\% of neutrophils to basal level when compared to the control mice. Further, all tested drugs caused high increase in the relative\% of basophils when compared to control.

In Fig. 1a, all tested drugs had increased BM cell count compared to saline-treated mice. Administration of Diclo $(7.4 \mathrm{mg} / \mathrm{kg}$ ) and Para (36.7 and $73.4 \mathrm{mg} / \mathrm{kg}$ ) showed significant increase in BM cell count. Total numbers of splenocytes had increased with treatment of Diclo (7.4 and $14.8 \mathrm{mg} / \mathrm{kg}$ ) related to control mice, while administration of Para (36.7 and $73.4 \mathrm{mg} / \mathrm{kg}$ ) or Ibu (60 and $120 \mathrm{mg} / \mathrm{kg}$ ) reduced splenocyte count (Fig. 1b).

The total number of thymocytes slightly decreased with Para (36.7 and $73.4 \mathrm{mg} / \mathrm{kg}$ ) compared to saline- 
Table 1 Cellular alternation in peripheral blood leucocytes profile of mice treated with Diclo, Ibu, and Para daily for 1 month

\begin{tabular}{|c|c|c|c|c|c|}
\hline \multirow[t]{2}{*}{ Treatments } & \multirow{2}{*}{$\begin{array}{l}\text { WBC count } \\
\left(\times 10^{3}\right)\end{array}$} & \multicolumn{4}{|c|}{ Leucocytes relative\% } \\
\hline & & Lymphocytes & Monocytes & Neutrophils & Basophils \\
\hline Control & $5.53 \pm 0.70$ & $79.80 \pm 4.40$ & $3.49 \pm 0.54$ & $12.81 \pm 0.46$ & $1.95 \pm 0.24$ \\
\hline Diclo (7.4mg/kg) & $7.80 \pm 0.60$ & $77.9 \pm 2.57$ & $6.17 \pm 0.38$ & $8.66 \pm 0.42^{* * *}$ & $7.23 \pm 1.01^{* * * *}$ \\
\hline Diclo (14 mg/kg) & $8.07 \pm 1.10$ & $77.63 \pm 0.20$ & $5.93 \pm 0.44$ & $12.72 \pm 1.38$ & $3.89 \pm 0.44$ \\
\hline Ibu (60 mg/kg) & $6.90 \pm 0.40$ & $78.10 \pm 7.11$ & $13.00 \pm 0.81^{* * *}$ & $10.24 \pm 0.08$ & $3.69 \pm 0.71$ \\
\hline Ibu (120 mg/kg) & $7.10 \pm 0.68$ & $75.80 \pm 3.26$ & $4.87 \pm 0.10$ & $8.30 \pm 0.65^{* * *}$ & $2.89 \pm 0.21$ \\
\hline Para (36.7 mg/kg) & $6.60 \pm 0.91$ & $80.46 \pm 7.50$ & $7.11 \pm 2.23$ & $11.30 \pm 0.46$ & $3.52 \pm 0.23$ \\
\hline Para (73.4 mg/kg) & $8.03 \pm 1.11$ & $75.22 \pm 2.79$ & $9.73 \pm 1.17^{* * *}$ & $10.91 \pm 0.29$ & $4.70 \pm 0.16^{*}$ \\
\hline
\end{tabular}

Data were represented as mean \pm SE $(n=3)$

"Statistically significant comparison of control group and other treated groups $(p<0.05)$, ***highly significant $(p<0.01)$

treated mice; however, administration of Diclo $(7.4 \mathrm{mg} /$ $\mathrm{kg}$ ) elevated thymocyte count that was reduced by increasing dose of Diclo $(14.8 \mathrm{mg} / \mathrm{kg})$. Ibu $(60 \mathrm{mg} / \mathrm{kg})$ had no change on thymocytes, but increasing dose of Ibu $(120 \mathrm{mg} / \mathrm{kg})$ revealed elevation of thymocytes (Fig. 2a). Similarly, the total number of lymph nodes increased with treatment of Diclo $(7.4 \mathrm{mg} / \mathrm{kg})$ which highly decreased with increasing dose of Diclo $(14.8 \mathrm{mg} /$ $\mathrm{kg})$, although Para- (36.7 and $73.4 \mathrm{mg} / \mathrm{kg})$ and Ibu $(60$ and $120 \mathrm{mg} / \mathrm{kg}$ )-treated mice did not differ significantly from the control mice in terms of their total number of lymph nodes (Fig. 2b).
In the term of serum biochemical analysis as shown in Fig. 3a, Diclo (7.4 and $14.8 \mathrm{mg} / \mathrm{kg}$ ), Ibu $(60 \mathrm{mg} / \mathrm{kg})$, and Para $(36.7$ and $73.4 \mathrm{mg} / \mathrm{kg}$ ) treatments had significantly changed values of ALT, though higher dose of Ibu $(120 \mathrm{mg} / \mathrm{kg})$ significantly reduced the elevation of ALT activity compared to the saline-treated group. Similarly, AST values were significantly decreased with increasing the dose of Diclo and Ibu when compared with salinetreated mice; however, increasing dose of Para resulted in the significant elevation of AST suggesting the difference in AST activity is due to the mechanism of action of each drug (Fig. 3b). Moreover, there was a minor

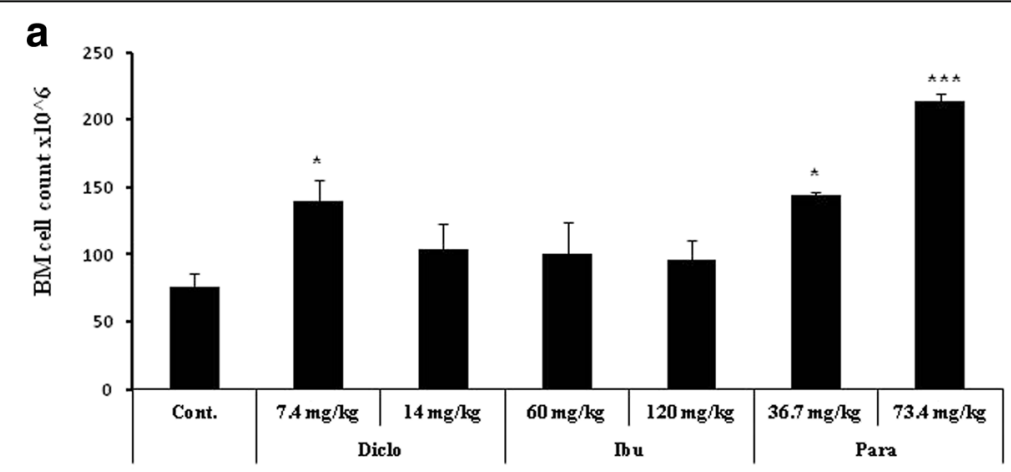

b

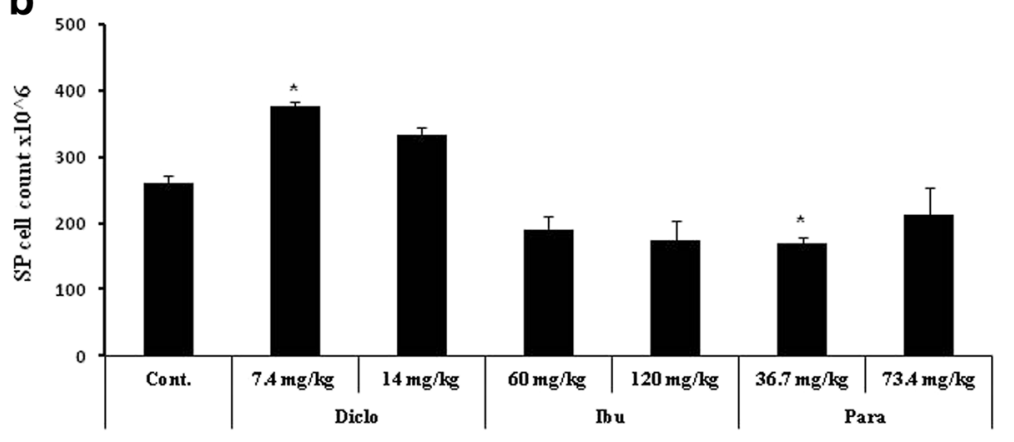

Fig. 1 Effect of repeated administration of Diclo, Ibu, and Para on a BM cell and $\mathbf{b}$ splenocyte count. Mice treated with saline (control), Diclo (7.4 and $14.8 \mathrm{mg} / \mathrm{kg}$ ), Para (36.7 and $73.4 \mathrm{mg} / \mathrm{kg}$ ), and Ibu1 (60 and $120 \mathrm{mg} / \mathrm{kg}$ ) intraperitoneally (i.p.) daily for 1 month. Data were represented as mean $\pm \operatorname{SE}(n=3)$. *Statistically significant comparison of control group and other treated groups $(p<0.05)$, **highly significant $(p<0.01)$ 

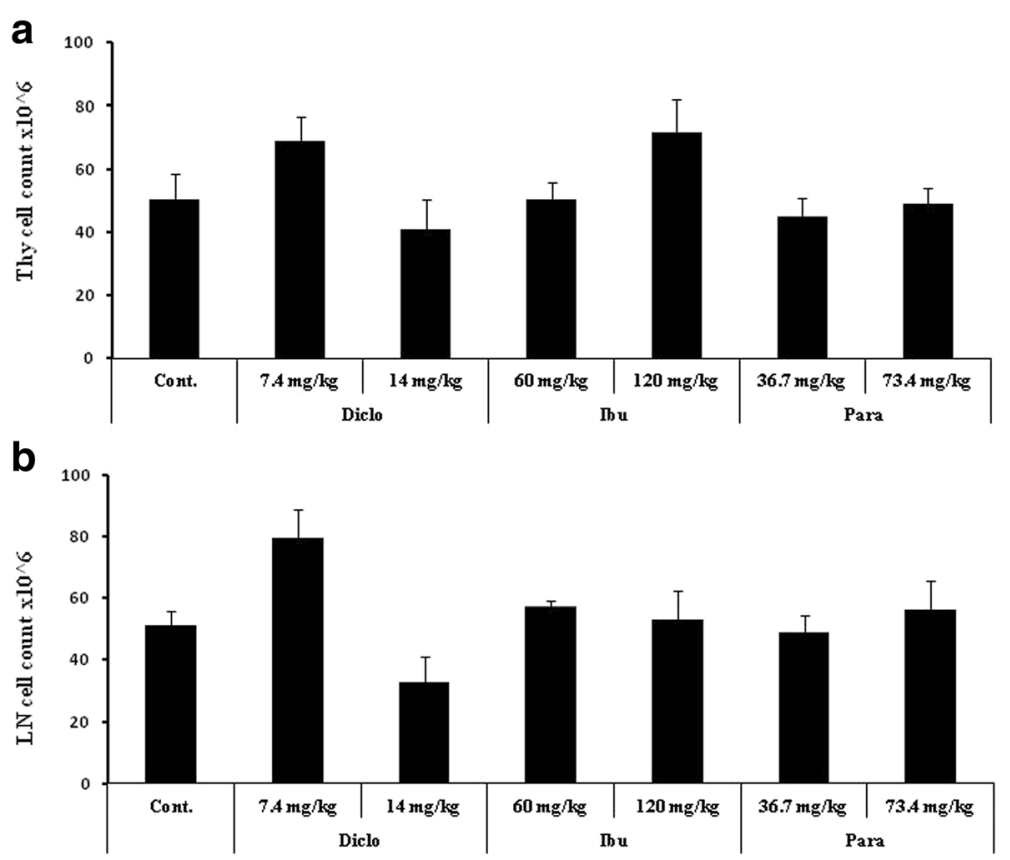

Fig. 2 Effect of repeated administration of Diclo, Ibu, and Para on a leucocyte count in thymus and $\mathbf{b}$ lymph node. Mice treated with saline (control), Diclo (7.4 and $14.8 \mathrm{mg} / \mathrm{kg}$ ), Para (36.7 and $73.4 \mathrm{mg} / \mathrm{kg}$ ), and lbu1 (60 and $120 \mathrm{mg} / \mathrm{kg}$ ) intraperitoneally (i.p.) daily for 1 month. Data were represented as mean $\pm \mathrm{SE}(n=3)$. ${ }^{*}$ Statistically significant comparison of control group and other treated groups $(p<0.05)$, **highly significant $(p<0.01)$

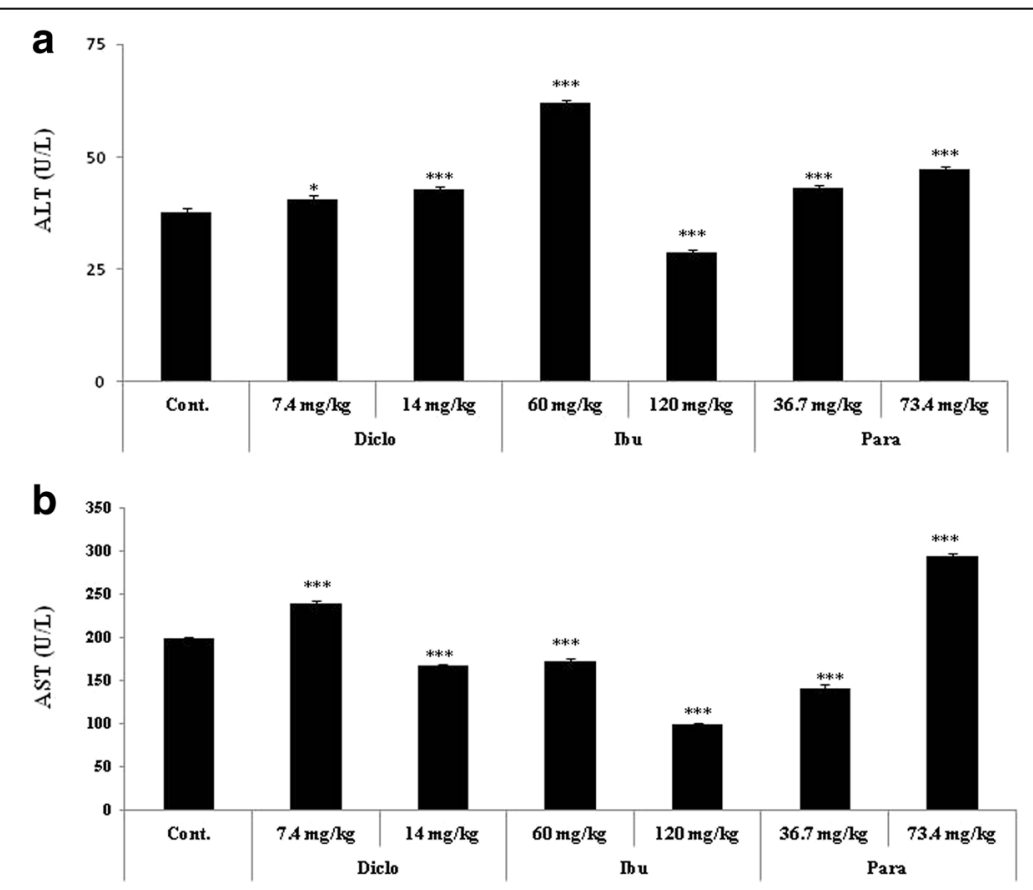

Fig. 3 Alternation of a ALT and b AST levels in PB after administration of Diclo, lbu, and Para. Mice treated with saline (control), Diclo1 (7.4 mg/kg), Diclo2 (14.8 mg/kg), Para1 (36.7 mg/kg), Para2 (73.4 mg/kg), Ibu1 (60 mg/kg), and lbu2 (120 mg/kg) intraperitoneally (i.p.) daily for 1 month. Data were represented as mean \pm SE $(n=3)$. *Statistically significant comparison of control group and other treated groups $(p<0.05)$, ***highly significant $(p<0.01)$ 
increase in urea and creatinine activities in all treatments compared to the control group, but not significantly (Fig. 4a, b).

\section{Discussion}

NSAIDs are effective and widely available in over-thecounter formulations without considering the relative contraindications, because they have analgesic, antipyretic, and anti-inflammatory actions (Am, 2009; El-Maddawy \& El-Ashmawy, 2013; Elazem \& Abo-Kora, 2015). Further, paracetamol is scrutinized as a derivative of para-aminophenol class of NSAIDs and broadly used in analgo-antipyretic purposes without medical prescription especially in childhood (Aghababian, 2010; Hamza \& Al-Harbi, 2015; Matić et al., 2016). The major goal of the current work was to explore the immunological and biochemical changes in mice after administration with repeated doses of Diclo, Ibu, and Para for 1 month.

WBC count is frequently used as indicators of health status. These cells are the important constituents of innate immune defense and are included in the control of immunological function in the organism (Ballarin, Dall'Oro, Bertotto, Libertini, \& Francescon, 2004). Current data revealed that administration of Diclo, Ibu, and Para for 1 month had no significant differences on total WBC count; however, the relative values of leukocytes indicated relative neutropenia, lymphopenia, monocytosis, and basophilia in all tested drugs depending on dose toxicity.

Similar results were speculated by Dadhaniya (2007) who observed that there was no significant change in the total WBC count in all the treatments of diclofenac sodium; however, leukocytes\% revealed relative lymphopenia in a dose-dependent manner (Thanagari et al, 2012) and significant neutropenia (Ibanez, Vidal, Ballarin, \& Lapote, 2005), possibly due to immune modulatory effects. Further, paracetamol treatment showed nonsignificant changes in total WBC (Oyedeji, Bolarinwa, \& Jeniran, 2013). Ibuprofen and other NSAIDs have been found to hinder the production of prostaglandins (Dawood, 1993) by the act of cyclooxygenase (COX) enzymes reducing the proliferation of human T-lymphocytes due to inhibition of binding of IL-2 to its receptors (Hall \& Wolf, 1997).

The present investigations further indicated that Diclo, Ibu, and Para drugs induced deleterious effects on immune-related organs (bone marrow, thymus, spleen, and lymph nodes). These results are in line with those of Liu et al. (2006) who revealed that infiltration of inflammatory cells into the liver in cases of direct druginduced hepatotoxicity deplete neutrophils from the periphery proposing a role of the innate immune system (e.g., neutrophils and macrophages) in protection against drug hepatotoxicity. Moreover, paracetamol is
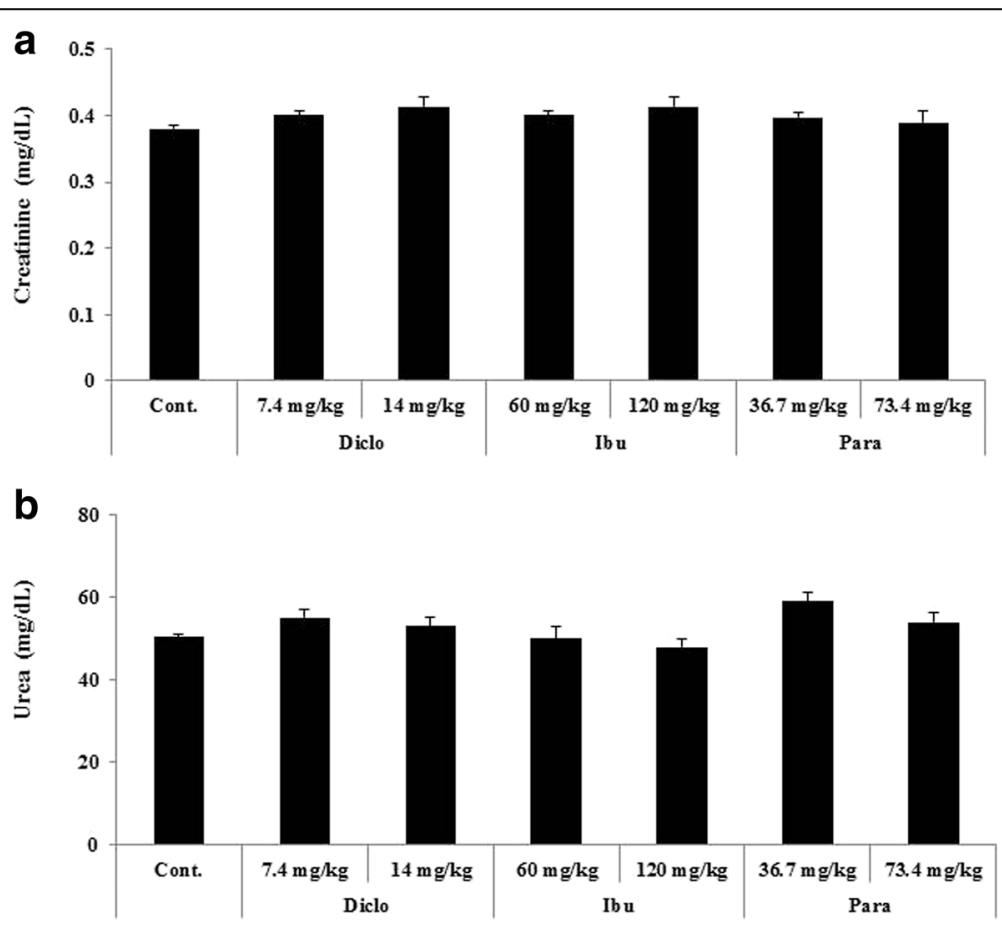

Fig. 4 Changes of level of $\mathbf{a}$ urea and $\mathbf{b}$ creatinine in PB after administration of Diclo, Ibu, and Para. Mice treated with saline (control), Diclo 1 (7.4 mg/kg), Diclo 2 (14.8 mg/kg), Para 1 (36.7 mg/kg), Para 2 (73.4 mg/kg), lbu1 (60 mg/kg), and lbu 2 (120 mg/kg) intraperitoneally (i.p.) daily for 1 month. Data were represented as mean \pm SE $(n=3)$. *Statistically significant comparison of control group and other treated groups $(p<0.05)$, ***highly significant $(p<0.01)$ 
metabolized into a toxic reactive metabolite that damage hepatocytes releasing danger signals, which triggers an innate immune response, leading to inflammation and collateral tissue damage to the liver and this may reduce leucocytes in the blood (Rainsford \& Velo, 2012). NSAIDs may cause thymocyte developmental defects and bone marrow suppression monitoring by the decrease in production of cells responsible for providing immunity (leukocytes). Also, they may differentially exert immunomodulatory effects on activated macrophages, granulocytes, and extrathymic $\mathrm{T}$ cells that become cytotoxic effector counter to self-tissues or self-cells when overactivated and these activated leukocytes may be closely related to the etiology of the tissue impairment inducible by NSAIDs (Yamamura, Arai, Toyabe, Takahashi, \& Abo, 1996; Cho, 2007; Aronson, 2009).

The biochemical markers used to assess liver function were ALT and AST which are the most sensible biomarkers promptly involved in the extent of hepatocellular injury (Chun, Tong, Busuttil, \& Hiatt, 2009; Singh, Bhat, \& Sharma, 2011) and their increase in serum is a marker of cellular outflow and lack of the functional integrity of cell membranes of hepatocytes (Rajesh \& Latha, 2004). The current investigations further showed that levels of serum ALT and AST were markedly changed by administration of Diclo, Ibu, or Para depending on dose and drug type. The present study draws a parallel with the research work of Bessone (2010) and Kishida et al. (2012) who reported that liver injury resulted from NSAIDs may be proposed to their acidic moiety or reactive metabolites that bind to host proteins causing cellular injury. Further, paracetamol is metabolized into a toxic reactive metabolite that binds to and depletes glutathione in the hepatocytes resulting in the impairment of mitochondrial function causing hepatocyte damage and necrosis. And this damage leads to cellular leakage and loss of functional integrity of cell membrane in liver releasing high levels of serum markers in the blood, notably AST and ALT that represents $90 \%$ of total enzyme and better index of liver injury (Watkins \& Seef, 2006; Ansari \& Asif, 2012).

Creatinine and urea levels are used as markers of kidney function due to chemical stresses, but the test for creatinine is more sensitive than urea (Vasudevan \& Sreekumari, 2007; Orinya, Adenkola, \& Ogbe, 2016). The results obtained herein revealed that, Diclo, Ibu, and Para administration for 1 month had no significant alternations in renal function (levels of urea and creatinine). In agreement with the present data, Qi et al. (2008) and Borges et al. (2013) reported that NSAIDs have a slight risk and effect on renal function and blood pressure in healthy humans and the incidence of hypertensive difficulties prompted by NSAIDs in patients may be associated with the degree and the selectivity of suppression of COX-2 in the kidney. And there were no significant variations relative to renal markers; however, negligible fluctuations in renal function were observed in ketoprofen and nimesulide groups, despite the normal clinical conditions of the studied dogs and the short time of therapy.

\section{Conclusions}

Based on the current results, it could be concluded that administration of diclofenac, ibuprofen, or paracetamol may induce immunological and biochemical perturbations, and their toxicity may increase depending on the dose. Further studies are desired to evaluate their toxicity in the biological system.

\section{Acknowledgements}

Not applicable.

\section{Funding}

The research reported is funded by a private partnership.

\section{Availability of data and materials}

The datasets generated and analyzed during the current study is available from the corresponding author on reasonable request.

\section{Ethics approval}

All animal experimentation protocols were approved by the Social Science Ethical Committee of Faculty of Science, Tanta University, and in agreement with the Ethical Principles for Animal Research established by Egyptian National Research Center, Cairo, Egypt.

Consent for publication

Not applicable.

\section{Competing interests}

The author declares no competing interests.

\section{Publisher's Note}

Springer Nature remains neutral with regard to jurisdictional claims in published maps and institutional affiliations.

Received: 7 August 2017 Accepted: 5 January 2018

Published online: 24 January 2018

\section{References}

Adams, S. S., Bough, R. G., Cliffe, E. E., Lessel, B., \& Mills, R. F. (1969). Absorption, distribution and toxicity of ibuprofen. Toxicology and Applied Pharmacology, 15(2), 310-330.

Aghababian, R., Jones \& Bartlett Publishers. (2010). Essentials of Emergency Medicine. Jones \& Bartlett Publishers, 814.

Am, S. (2009). Diclofenac induced toxic manifestations on adjuvant induced arthritic rats peripheral and reproductive organ of male wistar rats rattus norvegicus. Journal of Environmental Health Science, 1(1), 012-021.

Ansari, J. A., \& Asif, R. (2012). Hepatoprotective effect of Tabernaemontana divaricate against acetaminophen-induced liver toxicity. Medicinal Chemistry for Drug Discovery, 3(2), 146-151

Aprioku, J. S., \& Uche, F. I. (2013). Renal effects of non-steroidal antiinflammatory drugs in albino rats. British Journal of Pharmaceutical Research, 3(3), 314-325.

Aronson J.K., 2009. Side Effects of Drugs Annual 31: A Worldwide Yearly Survey of New Data and Trends in Adverse Drug Reactions. Elsevier Science Publishing Company, pp. 1-84

Aydin, G. I., Alparslan, G., Umen, K., Meral, N. C., Ekr, U. E., Nermin, K., \& Kalp, G. (2003). Histopathologic changes in liver and renal tissues induced by different doses of diclofenac sodium in rats. Turkish Journal of Veterinary and Animal Sciences, 27, 1131-1140. 
Ballarin, L., M. Dall'Oro, D. Bertotto, A. Libertini, A. Francescon, A. Barbaro Haematological parameters in Umbrinacirrosa (Teleostei, Sciaenidae): A comparison between diploid and triploid specimens. Comparative Biochemistry and Physiology. A., 138 (2004), pp. 138: 45-51.

Barr, J., Fraser, G. L., Puntillo, K., et al. (2013). Clinical practice guidelines for the management of pain, agitation, and delirium in adult patients in the intensive care unit. Critical Care Medicine, 41(1), 263-306.

Bessems, J. G., \& Vermeulen, N. P. (2001). Paracetamol (acetaminophen)-induced toxicity: Molecular and biochemical mechanisms, analogues and protective approaches. Critical Reviews in Toxicology, 37(1), 55-138.

Bessone, F. (2010). Nonsteroidal anti-inflammatory drugs: What is the actual risk of liver damage. World Journal of Gastroenterology, 16(45), 5651-5661.

Blondell, R. D., Azadfard, M., \& Wisniewski, A. M. (2013). Pharmacologic therapy for acute pain. American Family Physician, 87(11), 766-772.

Borges, M., Marini Filho, R., Laposy, C. B., Guimarães-Okamoto, P. T., Chaves, M. P., Vieira, A. N., \& Melchert, A. (2013). Nonsteroidal anti-inflammatory therapy: Changes on renal function of healthy dogs. Acta. Cirurgica Brasileira., 28(12), 842-847.

Bushra, R., \& Aslam, N. (2010). An overview of clinical pharmacology of ibuprofen. Oman Medical Journal, 25(3), 155-1661.

Cayman chemical company 2014, Materials safety data sheet: Diclofenac Sodium, Ellsworth, viewed 30 September 2014.

Cayman chemical company 2015, Materials safety data sheet: Acetaminophen, Ellsworth, viewed 14 June 2015

Cho, J. Y. (2007). Immunomodulatory effect of nonsteroidal anti-inflammatory drugs (NSAIDs) at the clinically available doses. Archives of Pharmacal. Research., 30(1), 64-74.

Chun, L. J., Tong, M. J., Busuttil, R. W., \& Hiatt, J. R. (2009). Acetaminophen hepatotoxicity and acute liver failure. Journal of Clinical Gastroenterology, 43(4), 342-349.

Dadhaniya, P. K. (2007). Sub-acutetoxicity study of diclofenac sodium on wistar rats, M.V.Sc. Thesis. Anand: Anand Agricultural University.

Dawood, M. Y. (1993). Nonsteroidal anti-inflammatory drugs and reproduction. American Journal of Obstetrics and Gynecology, 169, 1255-1265.

Diaz-Montero, C. M., Salem, M. L., Nishimura, M. I., Garrett-Mayer, E., Cole, D. J., \& Montero, A. J. (2009). Increased circulating myeloid-derived suppressor cells correlate with clinical cancer stage, metastatic tumor burden, and doxorubicin-cyclophosphamide chemotherapy. Cancer Immunology, Immunotherapy, 58(1), 49-59.

Elazem, A., \& Abo-Kora, S. Y. (2015). Adverse effects of Diclofenac potassium and Dexamethason on some hematobiochemical and immunological parameters in Egyptian goat bucks. Journal of American Science, 11(7), 92-99.

El-Maddawy, Z. K., \& El-Ashmawy, I. M. (2013). Hepato-renal and Haematological effects of diclofenac sodium in rats. Global Journal of Pharmacology, 7(2), 123-132.

Fonseca, R.J. (2017). Oral and Maxillofacial Surgery-E-Book: 3-Volume Set. Elsevier Health Sciences.

Hall, V. C., \& Wolf, R. E. (1997). Effects of tenidap and nonsteroidal antiinflammatory drugs on the response of cultured human $T$ cells to interleukin 2 in rheumatoid arthritis. The Journal of Rheumatology, 24(8), 1467-1470.

Hamza, R. Z., \& Al-Harbi, M. S. (2015). Amelioration of paracetamol hepatotoxicity and oxidative stress on mice liver with silymarin and Nigella Sativa extract supplements. Asian Pacific Journal of Tropical Biomedicine, 5(7), 521-531.

Higuchi, K., Umegaki, E., Watanabe, T., Yoda, Y., Morita, E., Murano, M., et al. (2009). Present status and strategy of NSAIDs-induced small bowel injury. Journal of Gastroenterology, 44(9), 879-888.

Hinson, J. A., Roberts, D. W., \& James, L. P. (2010). Mechanisms of acetaminophen-induced liver necrosis. Handbook of Experimental Pharmacology, 196, 369-405

Ibanez, L., Vidal, X., Ballarin, E., \& Lapote, J. R. (2005). Drug -induced neutropenia and Agranulocytosis. Archives of Internal Medicine, 165(8), 869-874.

Jaeschke, H., Williams, C. D., McGill, M. R., Xie, Y., \& Ramachandran, A. (2013). Models of drug-induced liver injury for evaluation of phytotherapeutics and other natural products. Food and Chemical Toxicology, 55, 279-289.

Juni, P., Rutjes, A. W., \& Dieppe, P. A. (2002). Are selective COX 2 inhibitors superior to traditional non steroidal anti-inflammatory drugs? British Medical Journal, 324(7349), 1287-1288.

Kishida, T., Onozato, T., Kanazawa, T., Tanaka, S., \& Kuroda, J. (2012). Increase in covalent binding of 5-hydroxydiclofenac to hepatic tissues in rats co-treated with lipopolysaccharide and diclofenac: Involvement in the onset of diclofenac-induced idiosyncratic hepatotoxicity. The Journal of Toxicological Sciences, 37(6), 1143-1156.

Klaassen, C. D. (2001). Casarett and Doull, s toxicology: The basic science of poison 6th eds. New York: the McGrau-Hill Companies Inc.

Labianca, R., Sarzi-Puttini, P., Zuccaro, S. M., Cherubino, P., Vellucci, R., \& Fornasari, D. (2012). Adverse effects associated with non-opioid and opioid treatment in patients with chronic pain. Clinical Drug Investigation, 32(1), 53-63.

Liu, Z. X., Han, D., Gunawan, B., \& Kaplowitz, N. (2006). Neutrophil depletion protects against murine acetaminophen hepatotoxicity. Hepatology, 43, 1220-1230.

Lutz, M. B., Kukutsch, N., Ogilvie, A. L., Rößner, S., Koch, F., Romani, N., et al. (1999). An advanced culture method for generating large quantities of highly pure dendritic cells from mouse bone marrow. Journal of Immunological Methods, 223(1), 77-92.

Matić, M. M., Milošević, M. D., Paunović, M. G., Ognjanović, B. I., Štajn, A. S., \& Saičić, Z. S. (2016). Paracetamol-induced changes of haematobiochemical and oxidative stress parameters in rat blood: Protective role of vitamin $\mathrm{C}$ and $\beta$-glucan. Kragujevac Journal of Science, 38, 135-146.

McCarberg, B., \& Gibofsky, A. (2012). Need to develop new nonsteroidal antiinflammatory drug formulations. Clinical Therapeutics, 34(9), 1954-1963.

McGill, M. R., Williams, C. D., Xie, Y., Ramachandran, A., \& Jaeschke, H. (2012). Acetaminophen-induced liver injury in rats and mice: Comparison of protein adducts, mitochondrial dysfunction, and oxidative stress in the mechanism of toxicity. Toxicology and Applied Pharmacology, 264(3), 387-394.

Mohammed, H. A. (2015). Toxic and histopathological changes of harmful effect of diclofenac sodium on some loose organs in albino rats for twelve weeks. Journal of Medical Science and Clinical Research, 3(3), 4694-4702.

Morgan, G. (1999). Benificial effects of NSAIDS in the gastrointestinal tract. European Journal of Gastroenterology \& Hepatology, 11(4), 393-400.

Nalamachu, S. (2013). An overview of pain management: The clinical efficacy and value of treatment. The American Journal of Managed Care, 19(14), 261-266.

Oaks, J. L., Gilbert, M., Virani, M. Z., Watson, R. T., Meteyer, C. U., Rideout, B. A., et al. (2004). Diclofenac residues as the cause of vulture population decline in Pakistan. Nature, 427(6975), 630-633.

Ong, C. K. S., Lirk, P., Tan, C. H., \& Seymour, R. A. (2007). An evidence-based update on non-steroidal anti-inflammatory drugs. Clinical Medicine \& Research, 5(1), 19-34.

Orinya, O. A., Adenkola, A. Y., \& Ogbe, R. J. (2016). Haematological and biochemical studies on the effect of diclofenac sodium on Wistar Rattus Norvegicus. International Journal of Biological and Chemical Sciences, 10(5), 2231-2242.

Oyedeji, K. O., Bolarinwa, A. F., \& Jeniran, S. S. (2013). Effect of paracetamol (acetaminophen) on haematological and reproductive parameters in male albino rats. Research Journal of Pharmacology, 7(2), 21-25.

Qi, Z., Hao, C. M., Langenbach, R. I., Breyer, R. M., Redha, R., Morrow, J. D., \& Breyer, M. D. (2008). Opposite effects of cyclooxygenase-1 and -2 activity on the pressor response to angiotensin II. The Journal of Clinical Investigation, 110, 61-69.

Rainsford, K. D. (2009). Ibuprofen: Pharmacology, efficacy and safety. Inflammopharmacology, 17(6), 275-342.

Rainsford K.D., Velo G.P., 2012. Side-Effects of Anti-Inflammatory Drugs: Part Two Studies in Major Organ Systems. Springer Science \& Business Media.

Rajesh, M. J., \& Latha, M. S. (2004). Preliminary evaluation of the antihepatotoxic activity of Kamilari, a polyherbal formulation. Journal of Ethnopharmacology, 1, 99-104.

Ramesh, N., Jayakumar, K., Narayana, K., \& Vijayasarathi, S. (2002). A study on toxicity of diclofenac in dogs. Indian Veterinary Journal, 79, 668-671.

Ripamonti, C. I., Bandieri, E., \& Roila, F. (2011). Management of cancer pain: ESMO clinical practice guidelines. Annals of Oncology, 22(6), 69-77.

Roelofs, P. D., R.A. Deyo, B.W. Koes, R.J. Scholten, M.W. Van Tulder, 2008. Nonsteroidal anti-inflammatory drugs for low back pain. Cochrane Database of Systematic Reviews, (1) Art. No.: CD000396.

Shafi, M., Garg, U. K., Saqib, N., Baba, O. K., Farid, B. D., \& Wali, A. (2012). Haemato-biochemical studies on Diclofenac, ibuprofen and Nimesulide induced toxicity in broilers. Nature, Environment and Pollution Technology, $11(4), 649-652$.

Singh, A., Bhat, T. K., \& Sharma, O. P. (2011). Clinical biochemistry of hepatotoxicity. Journal of Clinical Toxicology, 4, 001-0019.

Siroka, Z., \& Svobodova, Z. (2013). The toxicity and adverse effects of selected drugs in animals-overview. Polish Journal of Veterinary Sciences, 16(1), 181-191. 
Thanagari, B. S., Fefar, D. T., Prajapati, K. S., Jivani, B. M., Thakor, K. B., \& Patel, J. H.

(2012). Haemato-biochemical alterations induced by diclofenac sodium toxicity in Swiss albino mice. Veterinary World., 5, 417-419.

Vasudevan, D. M., \& Sreekumari, S. (2007). Textbook of biochemistry for medical students, (5th ed., p. 551). New Delhi: Jaypee Brothers Medical Publishers Ltd. Watkins, P. B., \& Seef, L. B. (2006). Drug induced liver injury: Summary of a single topic research committee. Hepatology, 43, 618-631.

Yamamura, S., Arai, K., Toyabe, S., Takahashi, H. E., \& Abo, T. (1996). Simultaneous activation of granulocytes and extrathymic $T$ cells in number and function by excessive administration of nonsteroidal anti-inflammatory drugs. Cellular Immunology, 173(2), 303-311.

Zerbini, L. F., Tamura, R. E., Correa, R. G., Czibere, A., Cordeiro, J., Bhasin, M., et al. (2011). Combinatorial effect of non-steroidal anti-inflammatory drugs and NF-KB inhibitors in ovarian cancer therapy. PLoS One, 6(9), 24285.

\section{Submit your manuscript to a SpringerOpen ${ }^{\odot}$ journal and benefit from:}

- Convenient online submission

- Rigorous peer review

- Open access: articles freely available online

- High visibility within the field

- Retaining the copyright to your article

Submit your next manuscript at $\gg$ springeropen.com 